CENDEKIA, Vol. 13. No. 1 April 2019

p-ISSN: 1978-2098; e-ISSN: 2407-8557

Https://soloclcs.org; Email: cendekiaoslo@gmail.com

Center of Language and Cultural Studies, Surakarta, Indonesia

Juriyah, Siti; Yulianto \& Duaji, Noverman. 2019. Pengaruh Faktor Fisiologi, Perhatian, Minat, Pemenuhan Kebutuhan, Pengalaman dan Suasana Hati terhadap Kualitas Layanan. Cendekia (2019), 13(1): 53-66. Htpps://doi.org/10.30957/cendekia.v13i1.56.

\title{
Pengaruh Faktor Fisiologi, Perhatian, Minat, Pemenuhan Kebutuhan, Pengalaman, dan Suasana Hati terhadap Kualitas Layanan
}

\author{
Siti Juriyah $^{1}$, Yulianto \& Noverman Duadji \\ FISIP, Universtias Lampung, Indonesia \\ ${ }^{1}$ Correspomding email: siti.juriah@staff.unila.ac.id
}

\begin{abstract}
The objective to be achieved through this research is to determine the factors that affect the quality of service for students of the Faculty of Medicine (FK), University of Lampung (Unila), both partially and simultaneously. This type of research is correlational research. The population of this study was 771 students in FK Unila, and the number of sample was set at 91 students. The data were collected using instruments that have been developed by researchers. Valid and reliable data were analyzed using the latest version of the SPSS software program. The output of this study concludes that there are significant effects between physiological factors, attention, interest, experience, and mood on the quality of services available at FK Unila, both partially and simultaneously.
\end{abstract}

Keywords: physiology, attention, interest, experience, service quality mood

\section{Https://doi.org/10.30957/cendekia.v13i1.56.}

\section{PENDAHULUAN}

Kepuasan pelanggan terhadap kualitas pelayanan yang diberikan oleh petugas pelayanan publik, dipengaruhi oleh beberapa faktor. Faktor-faktor tersebut antara lain faktor internal petugas pelayan publik, dan faktor eksternal pelayan publik. Faktor internal pelayan publik antara lain, kemampuan yang dimiliki, keramahan, ketelitian, kecepatan, kesopanan, kesantunan, familieritas pelayan, kemudahan, keseriusan, kecerdasan, inisiatif, kesediaan membantu atau menolong orang yang dilayani, kesesuai dengan prosedur, dan keseriusan yang diberikan.

Adapun faktor eksternal yang berpengaruh antara lain: kualitas sarana dan prasarana, seperti kualitas mesin, kualitas ruang tunggu, suhu udara ruang tunggu, kebersihan ruang pelayanan, kerapihan, warna ruangan, suara musik yang dilantunkan, kualitas tulisan (kejelasan), warna tulisan, seragam para petugas, sarana pendukung, menu yang tersedia, dan berbagai aspek eksternal lainnya.

Faktor eksternal yang bersifat prosedur, antara lain, kejelasan standar operasional prosedur (SOP) layanan yang digambarkan dalam bentuk diagram alur secara jelas (chart), kejelasan waktu yang dibutuhkan pada tiap-tiap langkah kegiatan pelayanan, lokasi-lokasi layanan yang tersusun dengan baik, petunjuk arah (papan penunjuk), dan aspek lain yang berkaitan dengan SOP. 
CENDEKIA, Vol. 13. No. 1 April 2019

p-ISSN: 1978-2098; e-ISSN: 2407-8557

Https://soloclcs.org; Email: cendekiaoslo@gmail.com

Center of Language and Cultural Studies, Surakarta, Indonesia

Juriyah, Siti; Yulianto \& Duaji, Noverman. 2019. Pengaruh Faktor Fisiologi, Perhatian, Minat, Pemenuhan Kebutuhan, Pengalaman dan Suasana Hati terhadap Kualitas Layanan. Cendekia (2019), 13(1): 53-66. Htpps://doi.org/10.30957/cendekia.v13i1.56.

Feigenbaum (1996:68) secara detail menjelaskan bahwa, "kualitas layanan merupakan bagian dari penilaian kinerja institusi. Semakin baik layanan yang diberikan oleh para petugas yang sudah dilatih, merupkan indikator tinggi rendahnya kinerja organisasi yang akan diberikan oleh para pelanggan di kemudian hari. Para pelayanan yang sudah disiapkan dengan baik, baik berkaitan dengan keterampilan, gerak tubuh, konstruksi kalimat, dan cara melakukan pelayanan sangat menentukan penilaian yang diberikan oleh para klien."

Sebagaimana diketahui bersama, penelitian ini dilaksanakan di FK Unila dalam melaksanakan tri darma perguruan tinggi khsusnya dalam memberikan layanan pendidikan dan pengajaran, maka akan sangat penting manakala layanan tersebut benarbenar berkualitas baik, sehingga mutu proses pendidikan dan pembelajaran yang sudah disiapkan dengan baik, akan menghasilkan sebuah mutu penilaian kualitas layanan yang baik pula.

Untuk melaksanakan pelayanan dengan baik, maka dibutuhkan sebuah kegiatan evaluasi dan monitoring secara terjadwal, terprogram, dan terlaksanakan dengan baik. Dengan kegiatan tersebut, seluruh kegiatan yang tidak sesuai dengan rencana yang sudah disusun akan dapat diminimalisasi dan akan dapat diperbaiki dengan segera tanpa harus menunggu proses pendidikan dan pembelajaran selesai.

Evaluasi atas mutu kinerja para pelayan pendidikan dalam hal ini tenaga kependidikan, sangat diperlukan manakala lembaga dalam hal ini FK Unila menghendaki terjadinya perbaikan secara terus menerus, dan dalam rangka meningkatkan kinerja para pegawai di bidang kependidikan yang selama ini disinyalir masih rendah. Rendahnya kinerja pegawai bagian pelayanan kepada mahasiswa yang selama ini sudah dirasakan oleh semua mahasiswa lebih disebabkan karena belum adanya evaluasi secara terprogram dan menyeluruh yang dilakukan dalam rangka perbaikan mutu layanan.

Saat ini, dengan adanya standar layanan prima apalagi seluruh Unit kerja yang ada di Universitas Lampung telah mendapatkan sertifikat ISO manajemen mutu layanan, maka tidak ada kata lain kecuali setiap hari Unila selalu berusaha untuk meningkatkan mutu layanan yang diberikan baik kepada mahasiswa, dosen, maupun kepada seluruh pemangku kepentingan eksternal lainnya.

Adalah suatu kenistaan, apabila pada satu sisi sudah mendapatkan sertifikat ISO mutu layanan tetapi di sisi lain, masih mendapatkan predikat buruk dari para pemangku kepentingan berkaitan dengan mutu layanan yang mereka peroleh.

Dialah Purwanto (2007:27) yang telah melakukan banyak penelitian berkaitan dengan mutu pelayanan di lembaga pendidikan baik akademi, univeritas, politeknik, maupun sekolah tinggi, yang menyimpulkan bahwa, "Peningkatan mutu layanan akan mempermudah bagi lembaga pendidikan dalam pencapaian visi dan misi, serta tujuan lembaga. Tanpa ada mutu layanan yang bagus, maka pencapaian visi, misi, dan tujuan lembaga akan mengalami banyak kendala."

Undang-undang yang mengacu tentang pendidikan yaitu UU No 20 tahun 2003 tentang sistem pendidikan Nasional khusunya pada pasal 45 menyebutkan bahwa, 
CENDEKIA, Vol. 13. No. 1 April 2019

p-ISSN: 1978-2098; e-ISSN: 2407-8557

Https://soloclcs.org; Email: cendekiaoslo@gmail.com

Center of Language and Cultural Studies, Surakarta, Indonesia

Juriyah, Siti; Yulianto \& Duaji, Noverman. 2019. Pengaruh Faktor Fisiologi, Perhatian, Minat, Pemenuhan Kebutuhan, Pengalaman dan Suasana Hati terhadap Kualitas Layanan. Cendekia (2019), 13(1): 53-66. Htpps://doi.org/10.30957/cendekia.v13i1.56.

"Setiap satuan pendidikan formal dan non-formal menyediakan sarana dan prasarana yang memenuhi keperluan pendidikan sesuai dengan pertumbuhan dan perkembangan potensi fisik, kecerdasan intelektual, sosial, emosional, dan kejiwaan peserta didik."

Kalau menengok Undang undang No: 5 tahun 2014 tentang aparatur sipil negara bahwa, semua ASN harus bekerja dengan baik, karena posisinya selain sebagai abdi negara juga sebagai pelayan masyarakat. Sudah seharusnya mereka memberikan layanan terbaik.

Khusus di FK Unila, jumlah tenaga kependidikan yang siap melayani yaitu sebanyak 72 Orang dengan perincian sebanyak 24 orang berstatus sebagai ASN dan sinya sebanyak 48 orang berstatus sebagai tenaga kontrak Badan Layanan Umum. (Subbag Perencanaan dan Kepegawaian FK Unila 2018)

Latar belakang masalah sebagaimana di paparkan di atas memberikan inspirasi bagi penulis untuk melakukan penelitian tentang, "pengaruh faktor fisiologi, perhatian, minat, pemenuhan kebutuhan, pengalaman, dan suasana hati terhadap kualitas layanan."

\section{LANDASAN TEORI}

Kata persepsi menurut Juwita (2014:34) "berasal dari bahasa Inggris yaitu kata perception, yang diambil dari bahasa latin perceptio, yang berarti menerima atau mengambil. Dalam arti, sebagai cara pandang tehadap sesuatu atau merupakan pemahaman atas hasil olah daya pikir. Dengan kata lain, persepsi berkaitan dengan faktor-faktor eksternal yang direspons melalui pancaindra, daya ingat, dan daya jiwa."

Sementara itu, ahli lain menjelaskan bahwa, "persepsi adalah proses yang menyangkut masuknya pesan atau informasi ke dalam otak manusia. Melalui persepsi manusia terus-menerus mengadakan hubungan dengan lingkungannya. Hubungan ini dilakukan lewat inderanya, yaitu indera penglihat, pendengar, peraba, perasa, dan pencium" (Slameto, 2010:102)

Sesuai pendapat di atas, ahli lain yaitu Toha (2009:141) menguraikan bahwa, "Proses kognitif yang dialami oleh setiap orang di dalam memahami informasi tentang lingkungannya, baik lewat penglihatan, pendengaran, penghayatan, perasaan, dan penciuman. Kunci untuk memahami persepsi adalah terletak pada pengenalan bahwa persepsi itu merupakan suatu penafsiran yang unik terhadap situasi, dan bukannya suatu pencatatan yang benar terhadap situasi."

Konsep yang searah juga disampaikan oleh Arindita (2003:84) perseperi sebagai, "Suatu proses pemberian arti atau makna terhadap lingkungan yang mecakup penafsiran obyek, penerimaan stimulus (sesuatu yang merangsang terjadinya respon tertentu) yang berperan sebagai input, pengorganisasian stimulus, dan penafsiran terhadap stimulus yang telah diorganisasikan dengan cara mempengaruhi perilaku dan pembentukan sikap."

Lebih lanjut Arindita (2003:45) menjelaskan bahwa persepsi adalah, "Penglihatan, bagaimana seseorang melihat sesuatu. Sedangkan pandangan yang luas mengartikannya sebagai, bagaimana seseorang memandang atau mengartikan sesuatu. Sebagian besar dari individu menyadari bahwa dunia yang sebagaimana dilihat tidak selalu sama 
CENDEKIA, Vol. 13. No. 1 April 2019

p-ISSN: 1978-2098; e-ISSN: 2407-8557

Https://soloclcs.org; Email: cendekiaoslo@gmail.com

Center of Language and Cultural Studies, Surakarta, Indonesia

Juriyah, Siti; Yulianto \& Duaji, Noverman. 2019. Pengaruh Faktor Fisiologi, Perhatian, Minat, Pemenuhan Kebutuhan, Pengalaman dan Suasana Hati terhadap Kualitas Layanan. Cendekia (2019), 13(1): 53-66. Htpps://doi.org/10.30957/cendekia.v13i1.56.

dengan kenyataan, jadi berbeda dengan pendekatan sempit, tidak hanya sekedar melihat sesuatu tapi lebih pada pengertiannya terhadap sesuatu tersebut."

Ahli lain seperi Suparyanto (2011:24) menguraikan bahwa, "Persepsi berarti analisis mengenai cara mengintegrasikan penerapan kita terhadap hal-hal di sekeliling individu dengan kesan-kesan atau konsep yang sudah ada, dan selanjutnya mengenali benda tersebut. Untuk memahami hal ini, akan diberikan contoh sebagai berikut: individu baru pertama kali menjumpai buah yang sebelumnya tidak kita kenali, dan kemudian ada orang yang memberitahu kita bahwa buah itu namanya mangga. Individu kemudian mengamati serta menelaah bentuk, rasa, dan lain sebagainya, dari buah itu secara saksama. Lalu timbul konsep mengenai mangga dalam benak (memori) individu. Pada kesempatan lainnya, saat menjumpai buah yang sama, maka individu akan menggunakan kesan-kesan dan konsep yang telah kita miliki untuk mengenali bahwa yang kita lihat itu adalah mangga. Dengan kata lain, dalam proses pembentukan persepsi dibutuhkan adanya objek atau stimulus yang berkaitan dengan alat indera dengan perantaraan syaraf sensorik, kemudian diteruskan ke otak sebagai pusat kesadaran (proses psikologis). Selanjutnya, dalam otak terjadilah sesuatu proses hingga individu itu dapat mengalami persepsi (proses psikologis)."

Ahli lain yakni, Toha (2009:34) menyebutkan, "Persepsi pada umumnya terjadi karena dua faktor, yaitu faktor internal dan faktor eksternal. Faktor internal berasal dari dlam diri individu, misalnya sikap, kebiasaan, dan kemauan. Sedangkan faktor eksternal adalah faktor-faktor yang berasal dari luar individu yang meliputi stimulus itu sendiri, baik sosial maupun fisik."

Hamka (2002:65) menjelaskan bahwa "ada empat karakteristik penting dari faktor-faktor pribadi dan sosial yang terdapat dalam persepsi, yaitu: a) Faktor-faktor ciri dari objek stimulus (sesuatu yang merangsang terjadinya respon tertentu), b) Faktorfaktor pribadi seperti intelegensi, minat, c) Faktor-faktor pengaruh kelompok, dan d) Faktor-faktor perbedaan latar belakang kultural."

Robbin, (2003:58) menguraikan bahwa, "Persepsi terhadap benda mati seperti meja, mesin atau gedung, persepsi terhadap individu adalah kesimpulan yang berdasarkan tindakan orang tersebut. Objek yang tidak hidup dikenai hukum-hukum alam tetapi tidak mempunyai keyakinan, motif atau maksud seperti yang ada pada manusia. Akibatnya individu akan berusaha mengembangkan penjelasan-penjelasan mengapa berperilaku dengan cara-cara tertentu. Oleh karena itu, persepsi dan penilaian individu terhadap seseorang akan cukup banyak dipengaruhi oleh pengandaianpengadaian yang diambil mengenai keadaan internal orang itu."

Ada beberapa faktor yang menurut Robbin (2003:58) yang mempengaruhi persepsi, yaitu, "Faktor-faktor yang mempengaruhi persepsi pada dasarnya dibagi menjadi 2 yaitu Faktor Internal dan Faktor Eksternal. Faktor Internal yang mempengaruhi persepsi, yaitu faktor-faktor yang terdapat dalam diri individu, yang mencakup beberapa hal antara lain: a) Fisiologis. Informasi masuk melalui alat indera, selanjutnya informasi yang diperoleh ini akan mempengaruhi dan melengkapi usaha untuk memberikan arti terhadap lingkungan sekitarnya. Kapasitas indera untuk 
CENDEKIA, Vol. 13. No. 1 April 2019

p-ISSN: 1978-2098; e-ISSN: 2407-8557

Https://soloclcs.org; Email: cendekiaoslo@gmail.com

Center of Language and Cultural Studies, Surakarta, Indonesia

Juriyah, Siti; Yulianto \& Duaji, Noverman. 2019. Pengaruh Faktor Fisiologi, Perhatian, Minat, Pemenuhan Kebutuhan, Pengalaman dan Suasana Hati terhadap Kualitas Layanan. Cendekia (2019), 13(1): 53-66. Htpps://doi.org/10.30957/cendekia.v13i1.56.

mempersepsi pada tiap orang berbeda-beda sehingga interpretasi terhadap lingkungan juga dapat berbeda; b) Perhatian. Individu memerlukan sejumlah energi yang dikeluarkan untuk memperhatikan atau memfokuskan pada bentuk fisik dan fasilitas mental yang ada pada suatu obyek. Energi tiap orang berbeda-beda sehingga perhatian seseorang terhadap obyek juga berbeda dan hal ini akan mempengaruhi persepsi terhadap suatu obyek; c) Minat. Persepsi terhadap suatu obyek bervariasi tergantung pada seberapa banyak energi atau perceptual vigilance yang digerakkan untuk mempersepsi. Perceptual vigilance merupakan kecenderungan seseorang untuk memperhatikan tipe tertentu dari stimulus atau dapat dikatakan sebagai minat; d) Kebutuhan yang searah. Faktor ini dapat dilihat dari bagaimana kuatnya seseorang individu mencari obyek-obyek atau pesan yang dapat memberikan jawaban sesuai dengan dirinya; e) Pengalaman dan ingatan. Pengalaman dapat dikatakan tergantung pada ingatan dalam arti sejauh mana seseorang dapat mengingat kejadian-kejadian lampau untuk mengetahui suatu rangsang dalam pengertian luas; f) Suasana hati. Keadaan emosi mempengaruhi perilaku seseorang, mood ini menunjukkan bagaimana perasaan seseorang pada waktu yang dapat mempengaruhi bagaimana seseorang dalam menerima, bereaksi dan mengingat."

Nawawi (2003:26) menyatakan pelayanan adalah sebagai, "Kegiatan yang dilakukan oleh seseorang atau sekelompok orang dengan landasan faktor materi melalui sistem, prosedur dan metode tertentu dalam rangka usaha memenuhi kepentingan orang lain sesuai dengan haknya. Pelayanan hakikatnya adalah serangkaian kegiatan, karena itu pelayanan merupakan sebuah proses. Sebagai proses, pelayanan berlangsung secara rutin dan berkesinambungan, meliputi seluruh kehidupan orang dalam masyarakat."

Groonros (1960:27) sebagaimana dikutip oleh Ratnaningsih dkk (2012:2) menyatakan pelayanan adalah, "Suatu aktivitas atau serangkaian aktivitas yang bersifat tidak kasat mata (tidak dapat diraba) yang terjadi sebagai akibat adanya interaksi antara konsumen dengan karyawan atau hal-hal lain yang di sediakan oleh perusahaan pemberi pelayanan yang dimaksudkan untuk memecahkan permasalahan konsumen atau pelanggan."

Sementara itu, Supranto (2006:227) menjelaskan bahwa, "Pelayanan atau jasa merupakan suatu kinerja penampilan, tidak terwujud dan cepat hilang, lebih dapat dirasakan dari pada dimiliki, serta pelanggan lebih dapat berpartisipasi aktif dalam proses mengonsumsi jasa tersebut."

Ahli lain seperti Tjiptono (2005:45) menyatakan bahwa kualitas pelayanan yaitu, "Sistem manajemen strategis dan integratif yang melibatkan semua manajer dan karyawan serta menggunakan metode kualitatif dan kuantitatif untuk memperbaiki secara berkesinambungan atas proses organisasi agar dapat memenuhi dan melebihi kebutuhan, keinginan dan harapan konsumen. Kualitas pelayanan berpusat pada suatu kenyataan yang ditentukan oleh konsumen. Interaksi strategi pelayanan, sistem pelayanan dan sumber daya manusia serta konsumen akan sangat menentukan keberhasilan dari manajemen perusahaan. Suatu cara perusahaan untuk tetap dapat unggul bersaing adalah memberikan jasa dengan kualitas yang lebih tinggi dari 
CENDEKIA, Vol. 13. No. 1 April 2019

p-ISSN: 1978-2098; e-ISSN: 2407-8557

Https://soloclcs.org; Email: cendekiaoslo@gmail.com

Center of Language and Cultural Studies, Surakarta, Indonesia

Juriyah, Siti; Yulianto \& Duaji, Noverman. 2019. Pengaruh Faktor Fisiologi, Perhatian, Minat, Pemenuhan Kebutuhan, Pengalaman dan Suasana Hati terhadap Kualitas Layanan. Cendekia (2019), 13(1): 53-66. Htpps://doi.org/10.30957/cendekia.v13i1.56.

pesaingnya secara konsisten. Harapan konsumen dibentuk oleh pengalaman masa lalunya, pembicaraan dari mulut ke mulut serta promosi yang dilakukan oleh perusahaan jasa, kemudian dibandingkannya. Hal terpenting adalah bersedia mendengarkan konsumen, perusahaan melakukan hubungan dengan konsumen dengan cara memenuhi harapan serta perhatian kepada konsumen."

\section{METODE}

Jenis penelitian ini adalah "Penelitian korelasional teknik kuesioner yang diberikan kepada 91 sampel dari populasi sebanyak 771 mahasiswa Fakultas Kedokteran Universitas Lampung. Pengambilan sampel menggunakan teknik proportional stratified random sampling sebanyak $10 \%$ untuk masing-masing angkatan. Data dianalisis dengan menggunakan metode statistik inverensial dengan regresi linier. Uji hipotesis dilakukan dengan menggunakan bantuan soft ware statistik SPSS Versi 19.0."

\section{HASIL}

FK Unila dirintis sejak tahun 1999 berlandaskan pada surat keputusan Rektor Universtias Lampung Nomor 014/J26/1999. Pada tahun 2002 Program Studi Pendidikan Dokter (PSPD) Unila dibuka melalui Surat Izin Penyelenggaraan PSPD dari Dirjen Dikti berdasarkan Surat Kepurusan Direktorat Jenderal Pendidikan Tinggi Departemen Pendidikan Nasional, Republik Indonesia, No. 3195/D/T/2002 tertanggal 28 Okt. 2002, PSPD Universitas Lampung, mulai menerima mahasiswa tahun 2002. PSPD Unila resmi menjadi FK Unila berdasarkan SK Peraturan Menteri Pendidikan Republik Indonesia Nomor 12 Tahun 2011 tanggal 15 Maret 2011.

Tujuan PSPD Fakultas Kedokteran Universitas Lampung yang akan dicapai pada tahun 2016-2020 adalah:

1. Terselenggaranya pendidikan dan pengajaran yang berkualitas dan berdaya saing dengan kekhususan agromedicine;

2. Terselenggaranya program pendidikan dokter yang dapat dijangkau oleh masyarakat;

3. Lulusan PSPD FK Unila menjadi dokter yang professional dan beretika sesuai dengan standar kompetensi dokter indonesia;

4. Terselenggaranya penelitian yang berkualitas dengan kekhususan agromedicine

5. Terselenggaranya pengabdian masyarakat berdayaguna;

6. Terjalinnya kerjasama dengan berbagai pihak yang mendukung.

Peningkatan mutu lulusan dilakukan melalui beberapa cara yaitu:

1. pelaksanaan kurikulum berbasis kompetensi dengan sistem problem based learning dan student centered learning;

2. pembelajaran bermutu dengan sarana dan prasarana memadai,

3. pelaksanaan laboratorium bermutu dan pelaksanaan tugas akhir bermutu;

4. penyediaan sistem informasi berupa kemudahan mengakses internet;

5. penyediaan buku dan jurnal di ruang baca fakultas dan perpustakaan pusat Universitas Lampung; 
CENDEKIA, Vol. 13. No. 1 April 2019

p-ISSN: 1978-2098; e-ISSN: 2407-8557

Https://soloclcs.org; Email: cendekiaoslo@gmail.com

Center of Language and Cultural Studies, Surakarta, Indonesia

Juriyah, Siti; Yulianto \& Duaji, Noverman. 2019. Pengaruh Faktor Fisiologi, Perhatian, Minat, Pemenuhan Kebutuhan, Pengalaman dan Suasana Hati terhadap Kualitas Layanan. Cendekia (2019), 13(1): 53-66. Htpps://doi.org/10.30957/cendekia.v13i1.56.

6. pelaksanaan Praktik Belajar Lapangan yang bertujuan untuk mendekatkan mahasiswa dengan masyarakat melalui kegiatan keluarga binaan;

7. pelaksanaan stase Ilmu Kedokteran Komunitas ke beberapa perusahaan yang bergerak di bidang agronomi, klinik dokter keluarga, dan Puskesmas;

8. pelaksanaan kegiatan penelitian dan pengabdian kepada masyarakat oleh dosen juga melibatkan mahasiswa;

9. pembinaan alumni dalam mempersiapkan UKMPPD bagi mahasiswa yang baru lulus program profesi dokter dan akan mengikuti UKMPPD;

10. pelaksanaan kegiatan mahasiswa untuk mengikuti kompetisi tingkat fakultas, universitas, tingkat nasional dan atau internasional.

Pengujian hipotesis diperlukan untuk mengetahui ada atau tidaknya pengaruh antara seluruh variabel bebas terhadap kualitas layanan di FK Unila yang disuguhkan kepada para mahasiswa menurut penilaian mahasiswa. Untuk menguji hipotesis digunakan rumus regresi linier sederhana dan berganda. Berdasarkan perhitungan analisis data SPSS diperoleh hasil seperti tampak pada tabel 1.

Tabel 1. Hasil Analisis Uji Regresi

\begin{tabular}{|c|c|c|c|c|}
\hline No. & Uraian & Nilai F & Taraf signifikansi & Kesimpulan \\
\hline 1 & Regresi X1-Y & 59,749 & $.000^{\mathrm{a}}$ & Signifikan \\
\hline 2 & Regresi X2-Y & 80,422 & $.000^{\mathrm{a}}$ & Signifikan \\
\hline 3 & Regresi X3-Y & 114,911 & $.000^{\mathrm{a}}$ & Signifikan \\
\hline 4 & Regresi X4-Y & 110,452 & $.000^{\mathrm{a}}$ & Signifikan \\
\hline 5 & Regresi X5-Y & 179,969 & $.000^{\mathrm{a}}$ & Signifikan \\
\hline 6 & Regresi X6-Y & 93,661 & $.000^{\mathrm{a}}$ & Signifikan \\
\hline 7 & Regresi X1-6-Y & 40,913 & $.000^{\mathrm{a}}$ & Signifikan \\
\hline
\end{tabular}

Sumber: Hasil Pengolahan Data Tahun 2018

Hasil uji analisis regresi diperoleh oputput "nilai atau koefisien F hitung (X1-Y) sebesar 59,749 dan nilai probabilitas yaitu $0,000<0,05$. Dengan nilai tersebut menunjukkan bahwa faktor fisiologis pegawai berpengaruh signifikan terhadap kualitas pelayanan di Fakultas Kedokteran Universtias Lampung."

F hitung (X2-Y) sebesar 80,422 dan nilai probabilitas yaitu $0,000<0,05$. Koefisien tersebut memberikan makna bahwa perhatian pegawai terhadap para mahasiswa yang dilayani berpengaruh secara nyata terhadap kualitas layanan yang diberikan oleh para tenaga kependidikan di FK Unila.

F hitung (X3-Y) sebesar 114,911dan nilai probabilitas yaitu $0,000<0,05$. Jadi, minat pegawai dalam melayani berpengaruh signifikan terhadap kualitas pelayanan di Fakultas Kedokteran Universtias Lampung.

F hitung (X4-Y) sebesar 110,452 dan nilai probabilitas yaitu $0,000<0,05$. Koefisien itu memberikan makna bahwa pemenuhan kebutuhan oleh pegawai terhadap mahasiswa yang dilayani berpengaruh signifikan terhadap mutu pelayanan yang diberikan oleh pihak lembaga. 
CENDEKIA, Vol. 13. No. 1 April 2019

p-ISSN: 1978-2098; e-ISSN: 2407-8557

Https://soloclcs.org; Email: cendekiaoslo@gmail.com

Center of Language and Cultural Studies, Surakarta, Indonesia

Juriyah, Siti; Yulianto \& Duaji, Noverman. 2019. Pengaruh Faktor Fisiologi, Perhatian, Minat, Pemenuhan Kebutuhan, Pengalaman dan Suasana Hati terhadap Kualitas Layanan. Cendekia (2019), 13(1): 53-66. Htpps://doi.org/10.30957/cendekia.v13i1.56.

F hitung (X5-Y) sebesar 179,969 dan nilai probabilitas yaitu 0,000<0,05 yang berarti bahwa koefisien itu memberi makna bahwa pengalaman pegawai memberikan kontribusi bagi peningkatan kualitas layanan yang disuguhkan kepada pra pemangku kepentingan.

F hitung (X6-Y) sebesar 93,661dan nilai probabilitas yaitu $0,000<0,05$ dengan demikina, nilai tersebut memberikan indikasi bahwa, suasana hati pegawai yang memberikan layanan berkaitan erat dengan kualitas pelayanan prima yang diberikan kepada para mahasiswa.

F hitung (X1,2,3,4,5,6-Y) sebesar 40,913 dan nilai probabilitas yaitu $0,000<0,05$. Dengan nilai tersebut menunjukkan bahwa faktor fisiologi, perhatian, minat, pemenuhan kebutuhan, pengalaman, dan suasana batin pegawai berpengaruh signifikan terhadap kualitas pelayanan di Fakultas Kedokteran Universtias Lampung

Untuk meyakinkan signifikan atau tidaknya pengaruh faktor-faktor di atas terhadap kualitas pelayanan dapat juga dilihat dengan uji t pada tabel 2 .

Tabel 2. Hasil Analisis Uji t

\begin{tabular}{|c|c|c|c|c|}
\hline No. & Uraian & Nilai t hitung & Taraf signifikansi & Kesimpulan \\
\hline 1 & Regresi X1-Y & 7,730 & $.000^{\mathrm{a}}$ & Signifikan \\
\hline 2 & Regresi X2-Y & 8,968 & $.000^{\mathrm{a}}$ & Signifikan \\
\hline 3 & Regresi X3-Y & 10,720 & $.000^{\mathrm{a}}$ & Signifikan \\
\hline 4 & Regresi X4-Y & 10,510 & $.000^{\mathrm{a}}$ & Signifikan \\
\hline 5 & Regresi X5-Y & 13,415 & $.000^{\mathrm{a}}$ & Signifikan \\
\hline 6 & Regresi X6-Y & 9,678 & $.000^{\mathrm{a}}$ & Signifikan \\
\hline 7 & Regresi X1-6-Y & 4,363 & $.000^{\mathrm{a}}$ & Signifikan \\
\hline
\end{tabular}

Sumber: Hasil pengolahan data tahun 2018

Kriteria pengujian hipotesis adalah tolak $\mathrm{H}_{0}$ jika $\mathrm{t}_{\text {hitung }}>\mathrm{t}_{\text {tabel }}$ dan sebaliknya. Untuk distribusi t yang digunakan, mempunyai degree of freedom (df) atau disebut juga derajat kebebasan $(\mathrm{dk}) ; \mathrm{dk}=(\mathrm{n}-2)$ dan taraf signifikan 0,05 .

Berdasarkan analisis data diketahui bahwa signifikansi seluruh penghitungan di $<0,05$ dengan demikian, seluruh $\mathrm{H}_{0}$ ditolak dan seluruh $\mathrm{H}_{1}$ diterima, sehingga dapat disimpulkan bahwa terdapat pengaruh yang signifikan antara faktor-faktor di atas terhadap kualitas pelayanan baik secara parsial maupun simultan (bersama-sama).

Adapun sumbangan persepsi mahasiswa terhadap kualitas pelayanan dapat ditabulasikan pada tabel 3 .

Berdasarkan hasil analisis korelasional Xy1 diketahui bahwa $\mathrm{R}$ hitung 0,634, nilai $\mathrm{R}$ kuadrat sebesar 0,402 , atau $40,2 \%$. Sehingga dapat disimpulkan bahwa faktor fisiologis memberikan kontribusi terhadap kualitas pelayanan sebesar 40,2\%. Sisa dari $40,2 \%$ yaitu $59,8 \%$ tentu dipengaruhi oleh faktor selain yang disebutkan di atas. 
CENDEKIA, Vol. 13. No. 1 April 2019

p-ISSN: 1978-2098; e-ISSN: 2407-8557

Https://soloclcs.org; Email: cendekiaoslo@gmail.com

Center of Language and Cultural Studies, Surakarta, Indonesia

Juriyah, Siti; Yulianto \& Duaji, Noverman. 2019. Pengaruh Faktor Fisiologi, Perhatian, Minat, Pemenuhan Kebutuhan, Pengalaman dan Suasana Hati terhadap Kualitas Layanan. Cendekia (2019), 13(1): 53-66. Htpps://doi.org/10.30957/cendekia.v13i1.56.

Tabel 3. Hasil Analisis Korelasi

\begin{tabular}{|c|r|r|r|c|}
\hline Model & Nilai $R_{\text {hitung }}$ & Nilai ${ }^{2}$ & $\begin{array}{c}\text { Nilai } \mathrm{R}^{2} \\
\text { penyesuaian }\end{array}$ & $\begin{array}{c}\text { Kesalahan } \\
\text { Perkiraan }\end{array}$ \\
\hline Ry1 & 0,634 & 0,402 & 0,395 & 17,809 \\
\hline Ry2 & 0,689 & 0,475 & 0,469 & 16,687 \\
\hline Ry3 & 0,751 & 0,564 & 0,559 & 15,210 \\
\hline Ry4 & 0,744 & 0,554 & 0,549 & 15,379 \\
\hline Ry5 & 0,818 & 0,669 & 0,665 & 13,244 \\
\hline Ry6 & 0,716 & 0,513 & 0,507 & 16,071 \\
\hline Ry1,2,3,4,5,6 & 0,863 & 0,745 & 0,727 & 11,966 \\
\hline
\end{tabular}

Sumber: Hasil pengolahan data tahun 2018

Analisis hubungan Xy2 didapatkan nilai $\mathrm{R}$ hitung 0,689, nilai $\mathrm{R}$ kuadrat sebesar 0,475 , atau $47,5 \%$. Sehingga dapat disimpulkan bahwa perhatian pegawai memberikan kontribusi terhadap kualitas pelayanan sebesar $68,9 \%$. Sisa atas perhitungan tersebut yakni 31,1\% ditentukan oleh variabel lain.

Penghitungan korelasi Xy3 dihasilkan $\mathrm{R}$ hitung 0,751, nilai $\mathrm{R}$ kuadrat sebesar 0,564 , atau 56,4\%. Sehingga dapat disimpulkan bahwa minat melayani memberikan kontribusi terhadap kualitas pelayanan sebesar 56,4\%. Sisa atas perolehan sebesar 43,6\% ditentukan oleh variabel lain yang belum masuk dalam penelitian ini

Proses penghitungan korelasi Xy4 didapatkan nilai $\mathrm{R}$ hitung 0,744 , nilai $\mathrm{R}$ kuadrat sebesar 0,554, atau 55,4\%. Dengan demikian dapat dinyatakan, bahwa pemenuhan kebutuhan mahasiswa memberikan kontribusi terhadap kualitas pelayanan sebesar $55,4 \%$. Sisa penghitungan sebesar $44,6 \%$ bisa jadi ditentukan oleh variabel yang belum masuk dalam analisis ini.

Hasil penghitungan atau analisis korelasi Xy5 didaptkan nilai $\mathrm{R}$ hitung sebesar 0,818 , nilai $\mathrm{R}$ kuadrat sebesar 0,669 , atau $66,9 \%$. Sehingga dapat disimpulkan bahwa pengalaman melayani memberikan kontribusi terhadap kualitas pelayanan sebesar $66,9 \%$. Variabel lain yang tidak diikutsertakan melalui penelitian ini mempunyai sumbangan sisanya yaitu sebesar $33,1 \%$

Penghitungan korelasi dengan mengggunakan uji Korelasi product moment menunjukkan bahwa Xy6 diperoleh koefisien $\mathrm{R}$ hitung 0,716 , nilai $\mathrm{R}$ kuadrat sebesar 0 , 513, atau 51,3\%. Dapat disimpulkan bahwa suasana hati saat melayani memberikan kontribusi terhadap kualitas pelayanan sebesar 51,3\%. Variabel lain yang tidak diteliti memberikan sumbangan sebesar $48,7 \%$.

Analisis korelasi product moment Xy1,2,3,4,5,6 diperoleh koefisien $\mathrm{R}$ hitung sebesar 0,863 , nilai $\mathrm{R}$ kuadrat sebesar 0,745 , atau 74,5\%. Sehingga dapat disimpulkan bahwa faktor fisiologis, perhatian, minat, pemenuhan kebutuhan, pengalaman, dan suasana hati kontribusi terhadap kualitas pelayanan sebesar $74,5 \%$. Sisa dari proses penghitungan sebesar $25,5 \%$ sangat ditentukan oleh variabel yang tidak menjadi kajian ini. 
CENDEKIA, Vol. 13. No. 1 April 2019

p-ISSN: 1978-2098; e-ISSN: 2407-8557

Https://soloclcs.org; Email: cendekiaoslo@gmail.com

Center of Language and Cultural Studies, Surakarta, Indonesia

Juriyah, Siti; Yulianto \& Duaji, Noverman. 2019. Pengaruh Faktor Fisiologi, Perhatian, Minat, Pemenuhan Kebutuhan, Pengalaman dan Suasana Hati terhadap Kualitas Layanan. Cendekia (2019), 13(1): 53-66. Htpps://doi.org/10.30957/cendekia.v13i1.56.

$\mathrm{R}^{2}$ adjusted merukaan koefisien $\mathrm{R}$ yang sudah sangat memperhatikan besar kecilnya sampel, dengan demikian pemilihan $\mathrm{r}$ adjusted, merupakan pilihan yang tepat.

\section{BAHASAN}

Berdasarkan hasil analisis diketahui bahwa persepsi mahasiswa terhadap Fakultas Kedokteran Universitas Lampung berada dalam kategori baik. Hal ini berpengaruh secara signifikan terhdap mutu layanan yang prima yang diberikan oleh para tenaga kependidikan di FK Universitas Lampung. Dengan demikian, untuk meningkatkan kualitas pelayanan dibutuhkan persepsi yang baik. Ketika persepsi mahasiswa sudah baik, maka penilaian mahasiswaan terhadap kualitas pelayanannya pun akan menjadi baik.

Sebagaimana dikatakan oleh Walgito (1993:43) bahwa "persepsi seseorang merupakan proses aktif yang memegang peranan, bukan hanya stimulus (sesuatu yang merangsang terjadinya respon tertentu) tetapi juga individu sebagai satu kesatuan dengan pengalaman-pengalamannya, motivasi serta sikapnya yang relevan dalam menanggapi stimulus (sesuatu yang merangsang terjadinya respon tertentu). Dengan demikian, ketika ingin membangun persepsi yang bagus kepada mahasiswa maka tenaga kependidikan harus mampu memberikan pengalaman yang baik dan motivasi yang baik, sehingga tumbuh kesan yang baik pula."

Sebagaimana diketahui, bahawa kualitas pelayanan kepada mahasiswa dapat dijadikan sebagai salah satu strategi meningkatkan kepuasan seluruh mahasiswa dan pemangku kepentingan. Oleh karena itu, hanya layanan primalah yang dapat memberikan kepuasan kepada mahasiswa.

Sebagaimana dikatakan oleh Arindita (2003:84) yang berpendapat bahwa "persepsi adalah suatu proses pemberian arti atau makna terhadap lingkungan yang mecakup penafsiran obyek, penerimaan stimulus (sesuatu yang merangsang terjadinya respon tertentu) yang berperan sebagai input, pengorganisasian stimulus, dan penafsiran terhadap stimulus yang telah diorganisasikan dengan cara mempengaruhi perilaku dan pembentukan sikap." Dengan demikian untuk meningkatkan perspesi maka pada saat mahasiswa memberikan arti atau makna terhadap kualitas layanan, maka tenaga kependidikan harus mampu memberikan obyek atau layanan yang baik, karena layanan yang baik tersebut yang akan dijadikan stimulus (input) bagi pembentukan sikap.

Hasil penelitian ini sebenarnya sesuai dengan pendapat Azzahy (2008:23) yang menerangkan bahwa, "Dalam psikologi kontemporer persepsi secara umum diperlakukan sebagai variable campur tangan (intervening variable), yang dipengaruhi oleh faktor-faktor stimulus (sesuatu yang merangsang terjadinya respon tertentu) dan faktor-faktor yang ada pada subjek yang menghadapi stimulus tersebut. Dengan kata lain, ketika ada campur tangan dari tenaga kependidikan dalam mempengaruhi persepsi mahasiswa dalam bentuk layanan yang bermutu, ditunjang lagi dengan faktor yang ada pada subyek tersebut merasa puas atas layanan yang mereka terima, maka persepsi mereka akan menjadi bagus, begitu juga sebaliknya." 
CENDEKIA, Vol. 13. No. 1 April 2019

p-ISSN: 1978-2098; e-ISSN: 2407-8557

Https://soloclcs.org; Email: cendekiaoslo@gmail.com

Center of Language and Cultural Studies, Surakarta, Indonesia

Juriyah, Siti; Yulianto \& Duaji, Noverman. 2019. Pengaruh Faktor Fisiologi, Perhatian, Minat, Pemenuhan Kebutuhan, Pengalaman dan Suasana Hati terhadap Kualitas Layanan. Cendekia (2019), 13(1): 53-66. Htpps://doi.org/10.30957/cendekia.v13i1.56.

Untuk menumbuhkan keyakinan, dapat juga dirujuk pendapat Mar'at (1991:34) yang menyatakan bahwa, "Proses persepsi merupakan suatu proses kognitif yang dipengaruhi oleh pengalaman, cakrawala, dan pengetahuan individu. Begitu juga dalam pembentukan persepsi perlu proses kognisi yang dilakukan oleh tenaga kependidikan sehingga tumbuh kesan, pengalaman, cakrawala dan pengetahuan dalam diri mahasiswa yang mengarahkan pada pembentukan persepsi yang baik atas kualitas layanan yang mereka terima."

Kondisi di atas, pada dasarnya sesuai dengan pendapat Mar'at (1991:35) yang mengatakan bahwa, "Proses pembentukan persepsi sebagai pemaknaan hasil pengamatan yang diawali dengan adanya stimuli. Setelah mendapat stimuli, pada tahap selanjutnya terjadi seleksi yang berinteraksi dengan proses seleksi. Proses seleksi terjadi pada saat seseorang memperoleh informasi, maka akan berlangsung proses penyeleksian pesan tentang mana pesan yang dianggap penting dan tidak penting." Begitu juga tentang pembentukan persepsi mahasiswa terhadap pelayanan di FK Unila, maka persepsi tersebut dapat terbentuk setelah mahasiswa melakukan pengamatan atas stimulus yang diberikan oleh para pemberi pelayanan dalam hal ini para tenaga kependidikan. Stimuli tersebut kemudian berinteraksi dengan kegiatan seleksi yang dilakukan oleh mahasiswa dalam bentuk seleksi terhadap layanan yang baik dan kurang baik. Ketika hasil seleksi tersebut menunjukkan bahwa layanan yang baik mendominasi hasil pengamatan, maka persepsi mereka akan baik, dan sebaliknya, ketika hasil seleksi tersebut menunjukkan bahwa layanan yang buruk mendominasi hasil pengamatan, maka persepsi mereka akan buruk juga.

Jadi memang benar apa yang dikatakan oleh Ratnamiasih (2011:50-57) yang menjelaskan bahwa, "Ada dua faktor yang mempengaruhi persepsi, yaitu: faktor fungsional yang juga disebut sebagai faktor personal atau perseptor, dan faktor struktural yang merupakan pengaruh yang berasal dari sifat stimulus fisik dan efek-efek yang ditimbulkan pada sistem syaraf individu." Begitu juga di FK, persepsi mahasiswa tumbuh karena adanya faktor funsional yang berasal dari personal pihak-pihak yang melayani, dan faktor struktural yang berasal dari sifat pelayanan (stimulus) dan efekefek yang timbul dalam pikiran mahasiswa setelah menerima pelayanan. Ketika kedua faktor tersebut baik, maka persepsi mereka juga akan baik, dan sebaliknya, ketika faktor fungsional (tenaga kependidikan) dan faktor struktural (sifat pelayanan) buruk, maka persepsi mahasiswa terhadap pelayanan yang mereka terima juga buruk.

Pembahasan di atas pada dasarnya sejalan dengan pendapat Gerungan (1996:65) yang mengemukakan bahwa, "Dengan adanya perpaduan dua aspek atau lebih dalam kelompok akan berpengaruh dan menyebabkan terjadinya perubahan persepsi pada seseorang. Begitu juga terkait dengan persepsi mahasiswa FK, maka dengan adanya perpaduan antara pihak yang melayani yang terpadu dengan situasi dan kondisi pelayanan yang kondusif akan mampu mempengaruhi persepsi mahasiswa. Jika kedunya bagus, maka persepsi mahasiswa terhadap pelayanan juga akan bagus."

Berkaitan dengan faktor-faktor yang mempengaruhi persepsi menurut Robbins (2003:56), "Pada dasarnya dibagi menjadi 2 yaitu faktor internal dan faktor eksternal." 
CENDEKIA, Vol. 13. No. 1 April 2019

p-ISSN: 1978-2098; e-ISSN: 2407-8557

Https://soloclcs.org; Email: cendekiaoslo@gmail.com

Center of Language and Cultural Studies, Surakarta, Indonesia

Juriyah, Siti; Yulianto \& Duaji, Noverman. 2019. Pengaruh Faktor Fisiologi, Perhatian, Minat, Pemenuhan Kebutuhan, Pengalaman dan Suasana Hati terhadap Kualitas Layanan. Cendekia (2019), 13(1): 53-66. Htpps://doi.org/10.30957/cendekia.v13i1.56.

Begitu juga dalam kaitannya dengan persepsi mahasiswa FK, juga dipengaruhi oleh dua faktor internal dari mahasiswa itu sendiri seperti Informasi masuk melalui alat indera, perhatian, kebutuhan, suasana hati selama di FK, pengalaman yang diperoleh selama di FK, dan keputusan setelah melihat dan merasakan atas kualitas layanan yang mereka terima.

Hasil penelitian ini juga sesuai dengan hasil penelitian Saraswati, Hamid dan Topowijono (2015:56) yang mengatakan bahwa, "Ada korelasi yang signifikan antara persepsi terhadap kualitas pelayanan. Semakin baik persepsi maka semakin baik pula penilaian terhadap kualitas pelayanan, dan sebaliknya. Begitu juga di FK Unila, bahwa persepsi mahasiswa yang bagus terbukti mampu meningkatkan kualitas pelayanan. Dengan demikian, persepsi mahasiswa perlu ditumbuhkan dengan baik, agar pada diri mahasiswa tumbuh persepsi yang baik. Ketika persepsi mereka sudah tumbuh dengan baik, maka penilaian mereka terhadap kualitas pelayanan nya pun akan juga baik."

\section{SIMPULAN}

Berdasarkah hasil analisis data dan pembahasan dapat disimpulkan bahwa:

1. ada pengaruh yang berarti antara faktor fisiologis terhadap mutu layanan di FK Universitas Lampung

2. hasil analisis menunjukkan bahwa perhatian berpengaruh secara nyata terhadap kualitas pelayanan di Fakultas Kedokteran Universitas

3. koefisien regresi sederhana menjukkan bahwa terdapat pengaruh yang signifikan antara minat terhadap kualitas pemberian layanan

4. pemenuhan kebutuhan terhadap para mahasiswa menunjukkan pengaru yang berarti terhadap mutu pelayanan prima di FK Unila

5. pengalaman memberikan pengaruh yang signifikan terhadap kualitas bermutu tidaknya pelayanan

6. suasana hati para pemberi layanan akan sangat mempengaruhi kualitas atau mutu pelayanan yang diberikan

7. terdapat pengaruh secara bersama-sama antara variabel fisiologis, variabel perhatian, variabel minat, variabel pemenuhan kebutuhan, variabel pengalaman, dan variabel suasana hati petugas pemberi layanan terhadap kualitas pelayanan di Fakultas Kedokteran Universitas

\section{DAFTAR PUSTAKA}

Arindita. S. 2003. "Hubungan antara Persepsi Kualitas Pelayanandan Citra Bank dengan Loyalitas Nasabah." Skripsi, Surakarta: Fakultas Psikologi UMS. Online: http://www.masbow.com/2009/08/apa-itu-persepsi.html diakses tanggal 4 Februari 2018:

Azzahy, Ghana Syakira. 2008. "Persepsi”. On-Line: http://syakirablog.blogspot.com/2008/11/tentang-persepsi.html diakses tanggal 5 Februari 2018 
CENDEKIA, Vol. 13. No. 1 April 2019

p-ISSN: 1978-2098; e-ISSN: 2407-8557

Https://soloclcs.org; Email: cendekiaoslo@gmail.com

Center of Language and Cultural Studies, Surakarta, Indonesia

Juriyah, Siti; Yulianto \& Duaji, Noverman. 2019. Pengaruh Faktor Fisiologi, Perhatian, Minat, Pemenuhan Kebutuhan, Pengalaman dan Suasana Hati terhadap Kualitas Layanan. Cendekia (2019), 13(1): 53-66. Htpps://doi.org/10.30957/cendekia.v13i1.56.

Feidenbaum, 1996. "Kendali Mutu Terpadu," terjemahan Hubaya Kandahjaya, Jakarta: Penerbit Erlangga.

Gerungan W.A. 1996. Psikologi Sosial, Bandung: PT Refika Aditama.

Hamka, M. 2002. "Hubungan Antara Persepsi Terhadap Pengawasan Kerja dengan Motivasi Berprestasi.” Skripsi. Surakarta: Universitas Muhammadiyah Fakultas Psikologi

Junivita. K. 2014. "Konsep Persepasi." On-line: http://www.uksw.edu/id. acessed 8 Februari 2018.

Mar'at. 1991. Sikap Manusia, Perubahan, serta Pengukurannya. Jakarta: Ghalia Indonesia

Nawawi, H. 2003. Manajemen SDM untuk Bisnis dan Kompetitif, Yogyakarta: Gadjahmada University Press.

Purwanto, 2007, Metodologi Penelitian Kuantitatif, Yogyakarta: Pustaka Pelajar

Ratnamiasih, Ina, dkk. 2012. Kepemimpinan, Pengendalian Organisasi, dan Keamanan Kerja serta Dampaknya Pada Kualitas Pelayanan Rumah Sakit di Bandung. Online: https://www.researchgate.net/publication/ diakses tanggal 1 Juli 2018

Robbin, S.P. 2003. Perilaku Organisasi, Jakart: Index.

Slameto, 2010, Belajar dan Faktor yang mempengaruhinya, Jakarta: Rineka Cipta

Suparyanto, 2011, Konsep Persepsi, diunduh dari http://drsuparyanto.blogspot.com/2011/07/konsep-persepsi.html tanggal 12 Juli 2018

Supranto, J. (2006). Pengukuran Tingkat Kepuasan Pelanggan untuk Menaikan. Pangsa Pasar. Jakarta : PT Rineka Cipta

Tjiptono, Fandy. 2005, Pemasaran Jasa, Edisi pertama, Yogyakarta; Penerbit. Bayumedia Publishing

Toha, Miftah. (2007). Kepemimpinan dalam Manajemen. Jakarta: PT. Raja. Grafindo Persada

Topowijono, Azizah, Naibaho, (2015), "Pengaruh Profitabilitas, Pertumbuhan Penjualan, Struktur Aktiva dan Ukuran Perusahaan Terhadap Struktur Modal", Jurnal Administrasi Bisnis (JAB), Vol. 28 No.1

Walgito, Bimo, 2003. Pengantar Psikologi Umum, Yogyakarta: ANDI. 
CENDEKIA, Vol. 13. No. 1 April 2019

p-ISSN: 1978-2098; e-ISSN: 2407-8557

Https://soloclcs.org; Email: cendekiaoslo@gmail.com

Center of Language and Cultural Studies, Surakarta, Indonesia

Juriyah, Siti; Yulianto \& Duaji, Noverman. 2019. Pengaruh Faktor Fisiologi, Perhatian, Minat, Pemenuhan Kebutuhan, Pengalaman dan Suasana Hati terhadap Kualitas Layanan. Cendekia (2019), 13(1): 53-66. Htpps://doi.org/10.30957/cendekia.v13i1.56. 